\title{
Mosul Dam Problem and Stability
}

\author{
Nadhir Al-Ansari ${ }^{*}$, Nasrat Adamo², Mahdi Rasheed Al-Hamdani' ${ }^{3}$, Kadhim Sahar ${ }^{4}$, \\ Riyadh E. A. Al-Naemi ${ }^{5}$
}

\author{
${ }^{1}$ Lulea University of Technology, Lulea, Sweden \\ ${ }^{2}$ Norrkoping, Sweden \\ ${ }^{3}$ Minister of Water Resources, Ministry of Water Resources, Baghdad, Iraq \\ ${ }^{4}$ D.G. State Organization of Dams and Reservoirs, Ministry of Water Resources, Baghdad, Iraq \\ ${ }^{5}$ D. Mosul Dam, Dams and Reservoirs, Ministry of Water Resources, Baghdad, Iraq \\ Email: *nadhir.alansari@ltu.se, nasrat.adamo@gmail.com, waterresmin@mowr.gov.iq, Wreserved_2008@mowr.gov.iq, \\ mosuldam@yahoo.com
}

How to cite this paper: Al-Ansari, N., Adamo, N., Al-Hamdani, M.R., Sahar, K. and Al-Naemi, R.E.A. (2021) Mosul Dam Problem and Stability. Engineering, 13, 105-124. https://doi.org/10.4236/eng.2021.133009

Received: February 8, 2021

Accepted: March 5, 2021

Published: March 8, 2021

Copyright (C) 2021 by author(s) and Scientific Research Publishing Inc. This work is licensed under the Creative Commons Attribution International License (CC BY 4.0).

http://creativecommons.org/licenses/by/4.0/

\begin{abstract}
Mosul Dam is located on the River Tigris about $60 \mathrm{~km}$ northwest Mosul in Iraq. It is the biggest dam where its storage capacity reaches 11.11 billion cubic meters at normal operational level ( $330 \mathrm{~m}$. above sea level). The dam was constructed on alternating beds of karistified limestone, gypsum and marl. This dam suffered from water seepage under its foundation since its operation in 1986. Grouting operations were implemented since that time to overcome this problem. This seepage is believed to be due to dissolution of gypsum beds under the foundation, which was not carefully considered by the designers. It was recommended by the international board of experts that the water level should be kept at or below 319 m.a.s.l. to minimize damages in case of the failure of the dam. ISIS occupied the dam site on 8 August 2014 and it was seized back from the hands of ISIS on the 16th of the same month. They did plenty of damage despite the short period they occupied the area. After that, the Iraqi Ministry of Water Resources rebuilt the damaged parts and used new grouting and maintenance program. Now, the dam looks very safe at $319 \mathrm{~m}$ water level at its reservoir. In addition, the impounding was raised 325 m.a.s.l. for few days and nothing abnormal was noticed.
\end{abstract}

\section{Keywords}

Mosul Dam, Grouting, Stability, Tigris River, Iraq

\section{Introduction}

Iraq is located in the northeastern part of the Arabian Peninsula (coordinates 33 $00 \mathrm{~N}, 4400 \mathrm{E}$ ) (Figure 1). It covers an area of 437,072 square kilometers and 

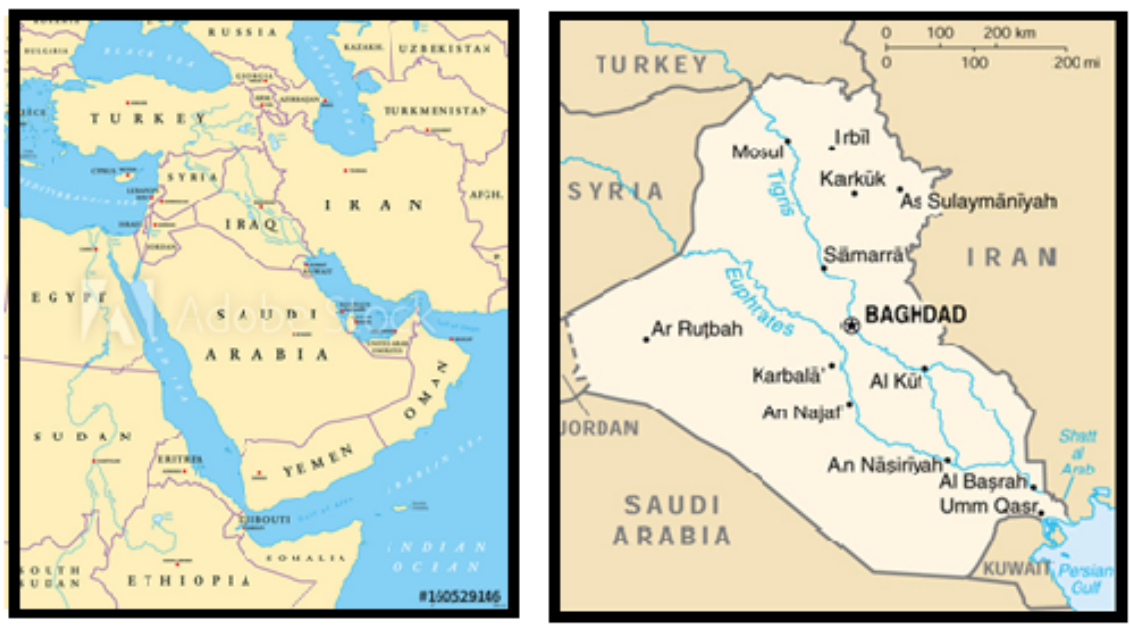

Figure 1. Location of Iraq.

population of about 40 million. The climate is mainly continental, subtropical and semi-arid [1]. The Tigris and Euphrates Rivers form the main water resources of Iraq. Both rivers rise in Turkey and the water coming from Turkey to Iraq is about $71 \%$ while about $6.9 \%$ and $4 \%$ come from Iran and Syria respectively (Figure 2) [2] [3] [4].

To protect the country from floods, ensure the required quantities of water for irrigation and for power generation, number of dams, barrages and hydrological projects were implemented [5]-[15]. The long-term average of the flow of the Tigris River is $21.2 \mathrm{~km}^{3}$ and its tributaries contribute $24.78 \mathrm{~km}^{3}$. The Euphrates contributes $30 \mathrm{~km}^{3}$ (which might fluctuate from 10 to $40 \mathrm{~km}^{3}$ ) [16] [17] [18]. All the water of the Euphrates River comes from outside the borders of Iraq while $67 \%$ of the Tigris water also comes from outside source [19].

Iraq used to consume about $42.8 \mathrm{~km}^{3}$ of water in 1990. Most of it is consumed for agricultural purposes (90\%) while $4 \%$ and $6 \%$ are consumed for domestic and industrial purposes. [19] [20] [21] stated that $85 \%$ of the water withdrawal is used for agricultural purposes recently. All urban areas received safe water supplies while $54 \%$ of rural areas receive safe water supplies. After the Gulf war, the situation deteriorated for water and sanitation sectors and accordingly $1 / 3$ of the population of Iraq do not have access to potable water [22].

Despite the fact that the Middle East is considered as arid to semi-arid area, Iraq used to be considered as rich in its water supplies until 1970. After that, the conditions changed due to climate change and construction of dams and irrigation projects by riparian countries [23]-[36]. In view of the current situation, it is of prime importance that Iraq should act to ensure water availability. One of the important measures to be taken in this context is the safety of the existing dams. In this context, Mosul Dam (the biggest dam in Iraq) experienced some problems [37]-[73]. This paper describes the problems of Mosul Dam and the measures taken to stabilize the dam. The goal of this work is to show the real status of the dam now. 


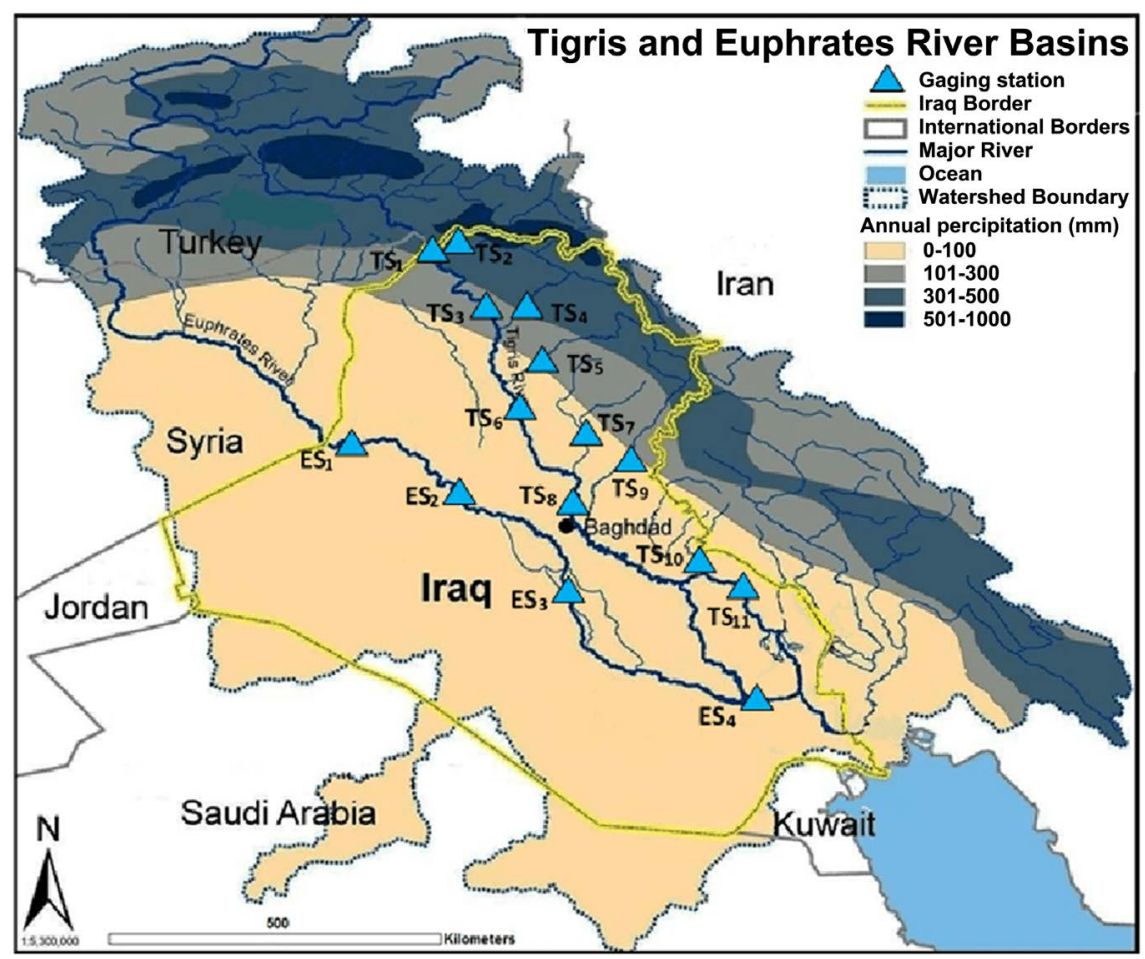

Figure 2. Sources of water for the Tigris and Euphrates Rivers (modified from [4]).

\section{Mosul Dam Project}

Mosul Dam is the biggest dam in Iraq and second biggest dam in the Middle East. It is located $60 \mathrm{~km}$ northwest of Mosul city (Figure 1 and Figure 3) [37] [38]. The construction of the dam started on 25 January 1981 and it started operating on 7 July 1986. The dam is multi objective projects where it provides water for three irrigation projects, flood control and hydropower generation. It is $113 \mathrm{~m}$ in height and $3650 \mathrm{~m}$ long including its spillway. Its top width is $10 \mathrm{~m}$ at 341 meters above sea level (a.s.l.). The normal, maximum and dead storage levels 330,335 and $300 \mathrm{~m}$ (a.s.l.). It is an earth fill type with a mud core. The reservoir is designed to impound $11.11 \mathrm{~km}^{3}$ at normal operational level $\left(8.16\right.$ and $2.95 \mathrm{~km}^{3}$ of live and dead storage respectively) (Figure 4). The dam has a concrete spillway located on the left abutment and has five radial gates measuring $13.5 \mathrm{~m} \times$ $13.5 \mathrm{~m}$ giving a discharge of $12,600 \mathrm{~m}^{3} \cdot \mathrm{sec}^{-1}$ at the maximum reservoir level of $338 \mathrm{~m}$ (a.s.l.) and its crest elevation of the spillway is $330 \mathrm{~m}$ (a.s.l.) and its length is $680 \mathrm{~m}$ [38]. The power generation facilities are located on and in the right abutment of the main dam and at the crest of the nearby hill the hydropower pumping storage is located (Figure 3). At the toe embankment of the dam, the powerhouse is located (Figure 3 ) and includes four turbines with total generating capacity of $750 \mathrm{MW}$ and the pumping storage generates $240 \mathrm{MW}$. At the northern part of the reservoir, North Al-Jazeera pumping station is located with a maximum water discharge $45 \mathrm{~m}^{3} \cdot \mathrm{sec}^{-1}$ (Figure 3) [38].

The reservoir of Mosul Dam is almost elongated shape where the River Tigris enters the upper zone and expands close to the dam site. Its length is about 45 

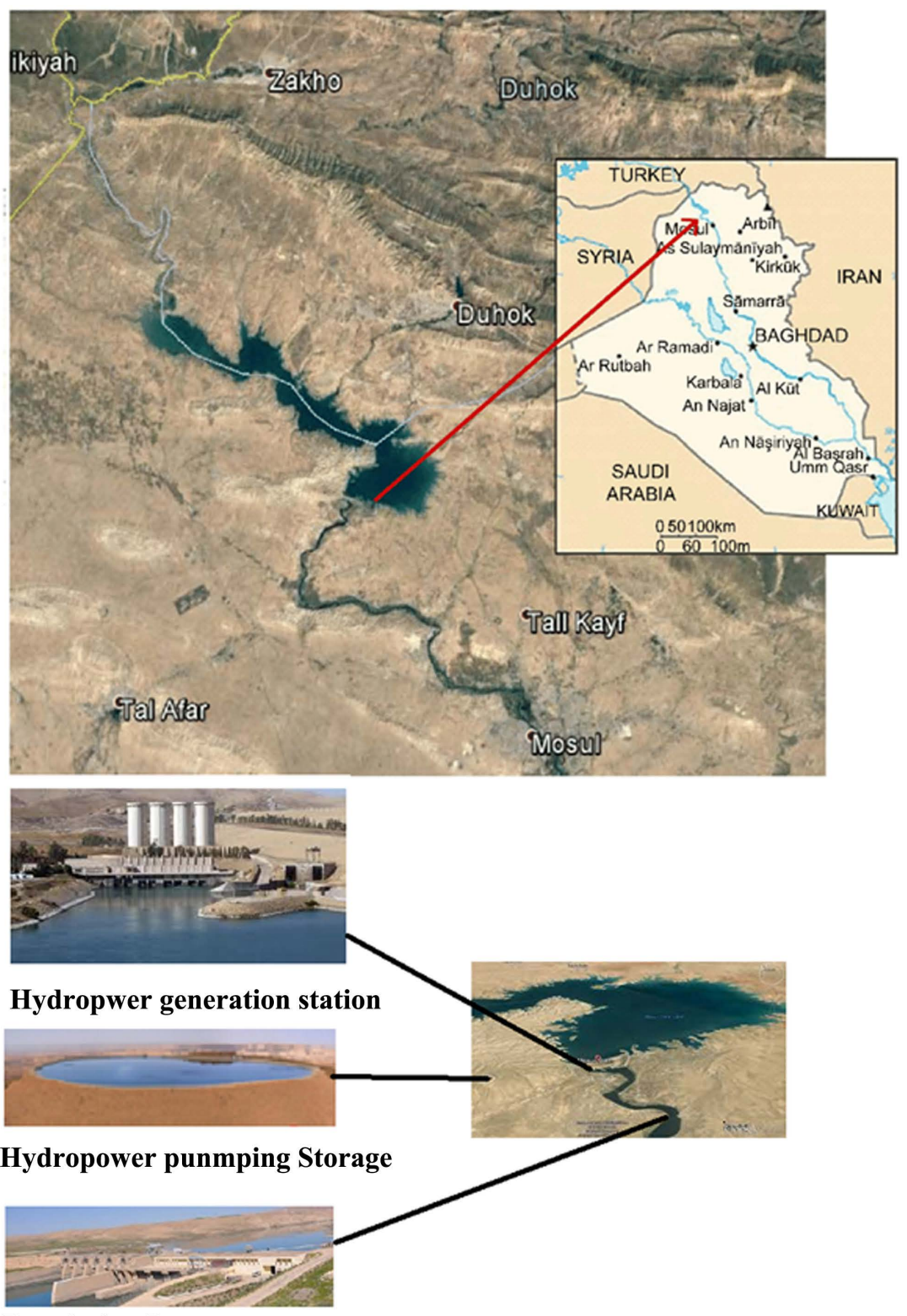

Regulating Dam

Figure 3. Location of Mosul Dam with main facilities.

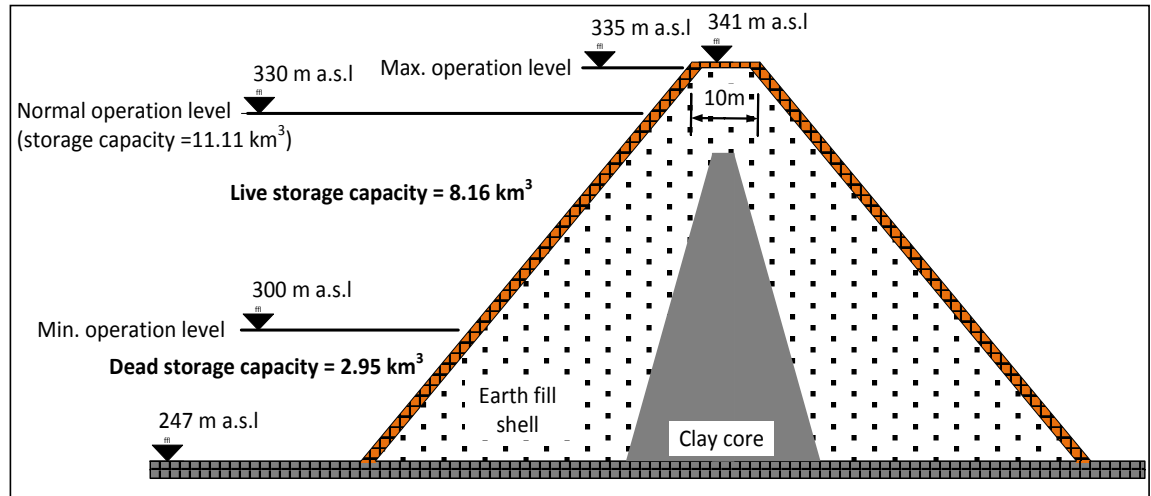

Figure 4. Schematic diagram of Mosul Dam cross section. 
$\mathrm{km}$ and its width ranges from 2 to $14 \mathrm{~km}$ with a water surface area of about 380 $\mathrm{km}^{2}$ at the maximum operation level of $330 \mathrm{~m}$ (a.s.l.). There are ten main valleys that feeding the reservoir (7 from the left side and 3 from the right side) [39].

\section{Geology of the Area}

The dam lies parallel to Butmah East anticline which is trending E-W with a gentle northern limb. The exposed rocks within the dam site and its reservoir area are the limestone and dolostone beds with soft marl beds of the Euphrates Formation (Lower Miocene) and the Fatha Formation (Middle Miocene) which consists of two members (Lower and Upper). The geology of the area is very complicated and for this reason number of investigations were carried out [40]-[49]. These members consist of cyclic sediments starting with green soft marl, hard limestone and hard gypsum (Figure 5 and Figure 6). Due to the inhomogeneity of the rocks; in their mechanical behavior will certainly behave differently when are loaded.

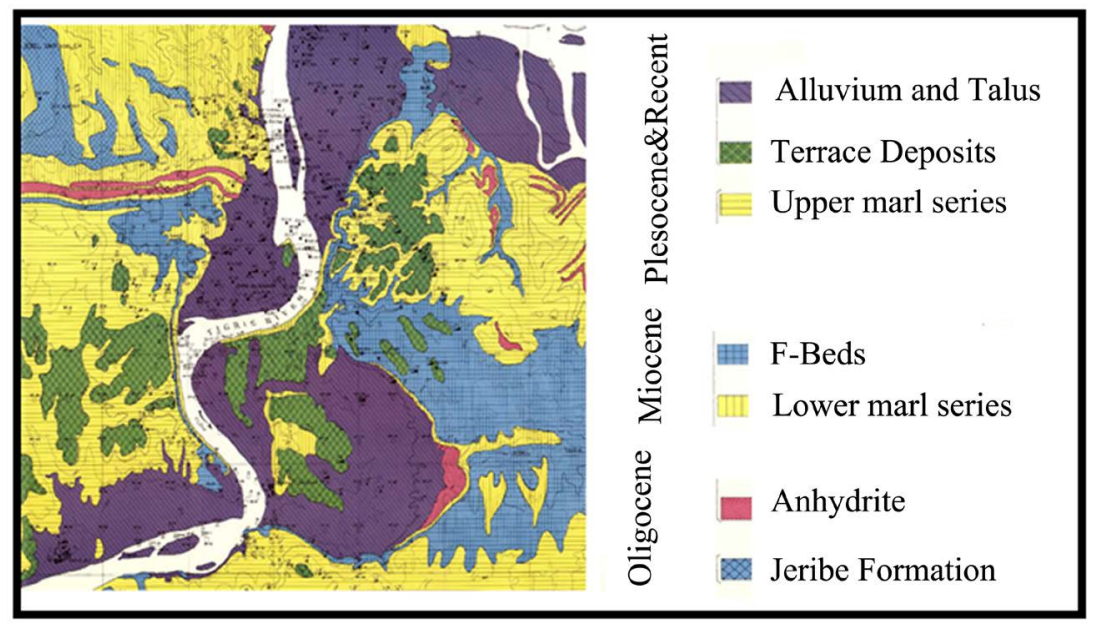

Figure 5. Geologic map of Mosul Dam site area (After [48]).

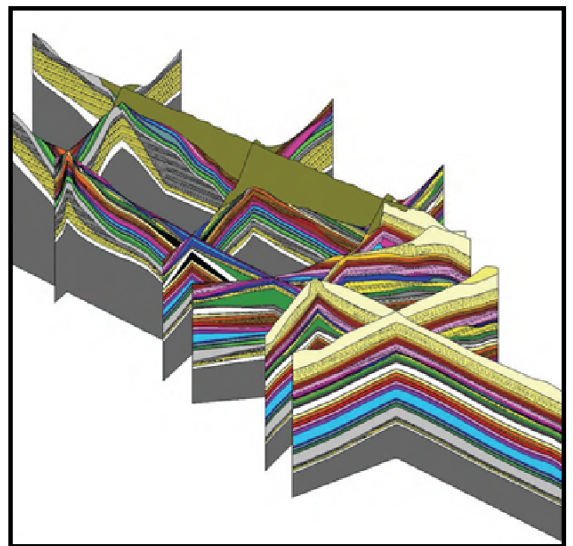

Figure 6. Intersecting cross sections from intermediate version of ERDC geologic conceptual model, showing complex stratigraphy and partial resolution of discrepancies in stratigraphy at intersections of the geologic panels from generated boreholes. (After [49]). 
Gypsum and limestone beds are usually karstified, but the karstification is less in the Upper Member as compared to Lower Member of the Fatha Formation. This is due to the presence of more clastics in the Upper Member than that of the Lower Member of the Fatha Formation, besides that gypsum and limestone beds become thin in the uppermost parts of the formation. [50] [51]. The most influential geological feature is the karstification especially in the foundation's rocks [41] [45] [50]-[55].

\section{Problem of Mosul Dam}

The nature of the rocks (e.g. limestone and gypsum) within the abutments and foundations Mosul Dam site (Figure 7) have high dissolution ability, which are

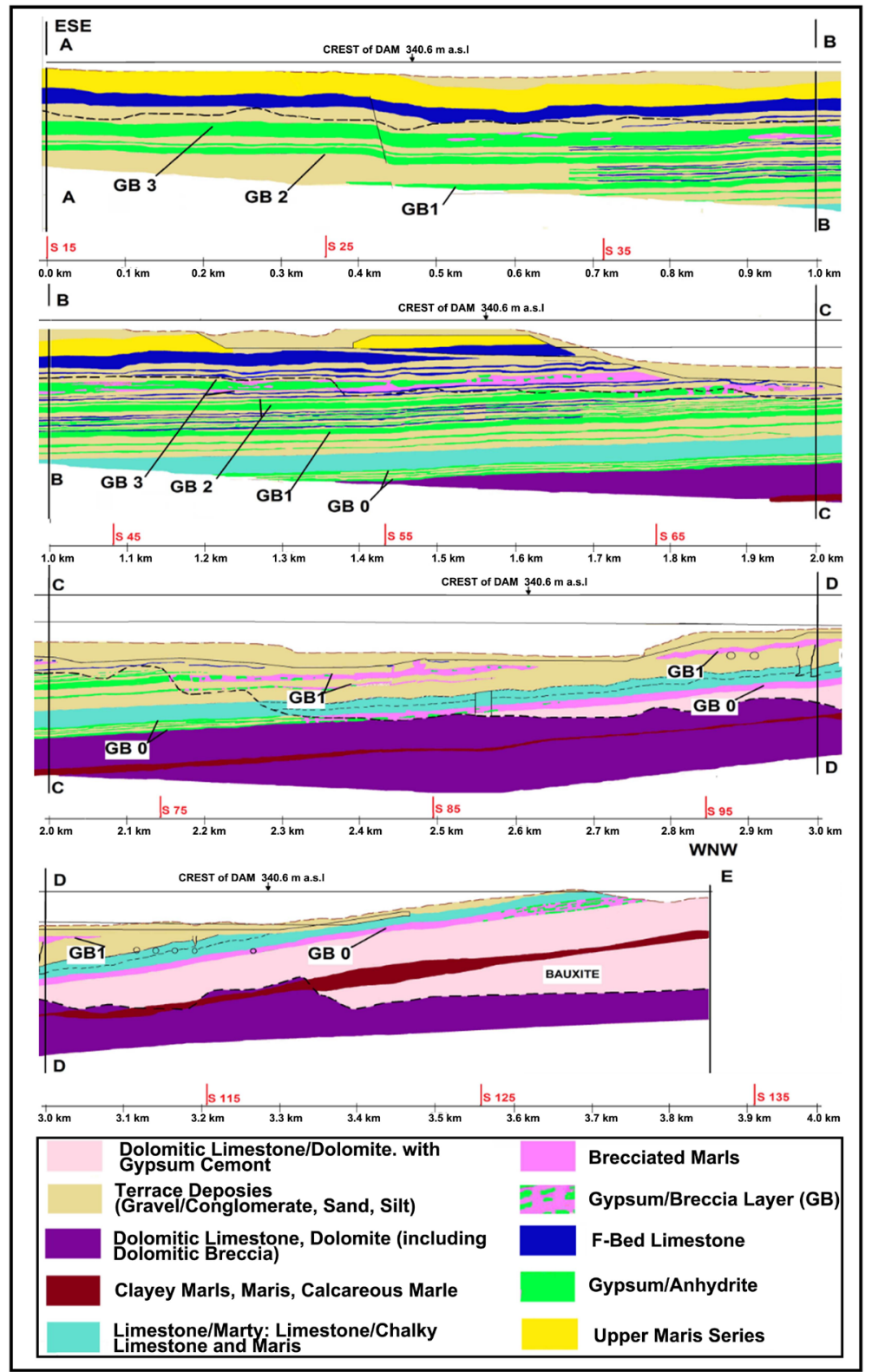

Figure 7. Geologic cross sections along the axis of the dam ([47]). 
highly karstified [47] (Al-Ansari et al., 2015). Most of the karst forms are sinkholes that were developed in gypsum and/or limestone [56]-[67] (Figures 8-10). The karst extends to a depth of about $100 \mathrm{~m}$ below the dam foundation (Figure 8).

Sinkholes in the downstream of the dam are believed to be developed due to fluctuations in the tail water level of the main dam during operation of the dam and the down-stream regulating reservoir [41] (Washington Group International, 2005). Before the impoundment of the reservoir, substantial flows of order of $360 \mathrm{l} / \mathrm{s}$ were noticed from a gypsum layer found during excavation of the tailrace tunnel for the pumped storage scheme. The seepage water had a high sulphate content, which was different from the reservoir water (Figure 9(B)). These

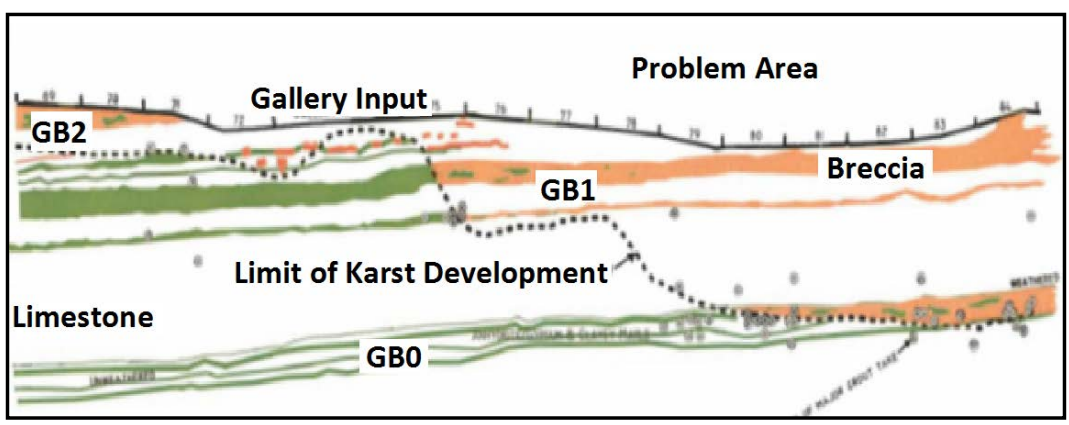

Figure 8. Location of the Karst line ([55]).

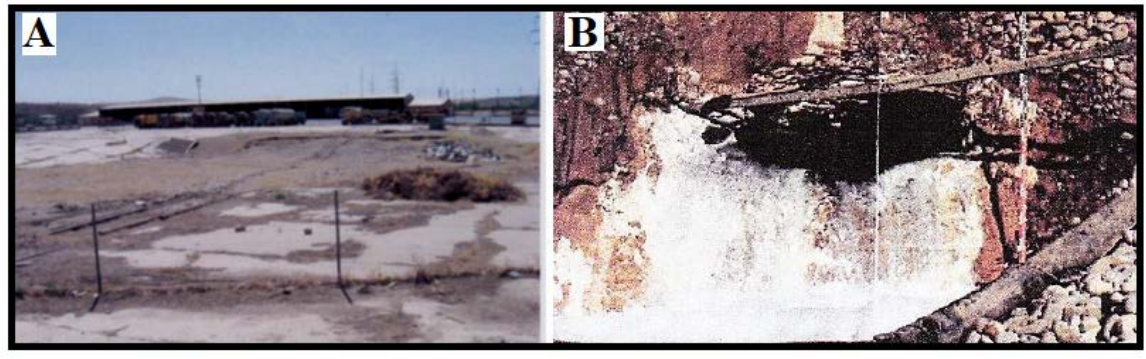

Figure 9. (A) One of the four sinkholes which had appeared in the 90's at the downstream right bank near the contractor yard. (B) Spring of discharge $360 \mathrm{l} / \mathrm{s}$ which is connected to the ground water aquifer connected to the reservoir ([47]).

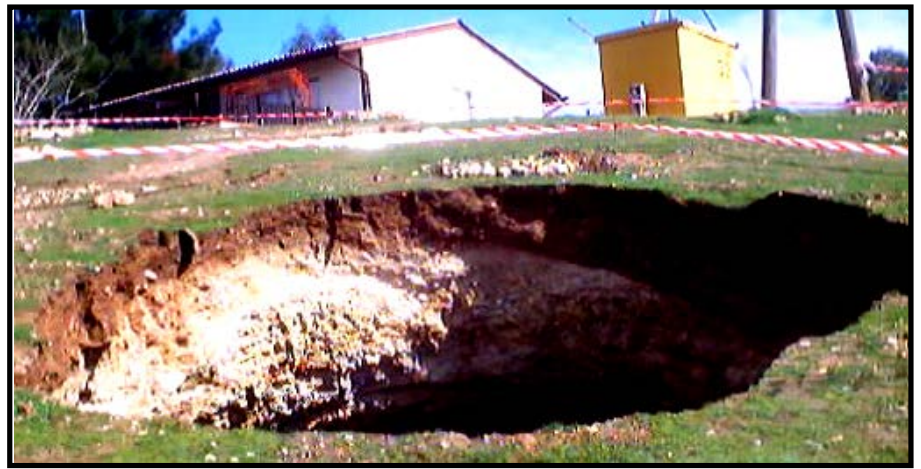

Figure 10. An example of sinkhole that apeared in 2003. The left bank sinkhole after full development ([47]). 
sinkholes are believed to be connected to the aquifer on the right bank of the reservoir. There are other forms of features such as Karren, shafts, channels also. When the reservoir was filled to its normal operational level (330 $\mathrm{m}$ a.s.l.) for the first time new sinkholes appeared downstream (Figure 10). In addition, many other seepages were observed with high sulphide water which indicates dissolution of the gypsum [57].

The operation of the reservoir had led to a new groundwater dynamic that accelerated the dissolution of gypsum under the foundation of the dam and within the reservoir area. A sediment and bathymetric survey was conducted during 2011 to the reservoir area and the bathymetric map (Figure 11) showed formation of sinkholes within the bottom of the reservoir [68]-[75].

In addition to the above, several researches were conducted to check the stability of Mosul Dam [76] [77] [78] [79] [80]. Settlite based work indicated that there is local differential settlement in the body of Mosul Dam. The results of different work published showed that the settlement varies from $5-15 \mathrm{~mm}$ /year [76] [77] [78] [79] [80]. This subsidence is believed to be mainly due to heterogeneous decline in the dictates of the dam and not in the foundations according to the consultants who designed the Mosul Dam.

\section{Protective Measures}

In view of the situation of Mosul Dam that has been discussed above, there were several measures taken to overcome the problem. These measures can be summarized in this section.

Grouting operations were carried out since the start of building the dam to overcome the problem of karstification and jointing of the rocks [56]-[67]. Blanket grouting was done under the core of the main dam. The purpose of this type of grouting was to make sure to fill all the openings due to karstification

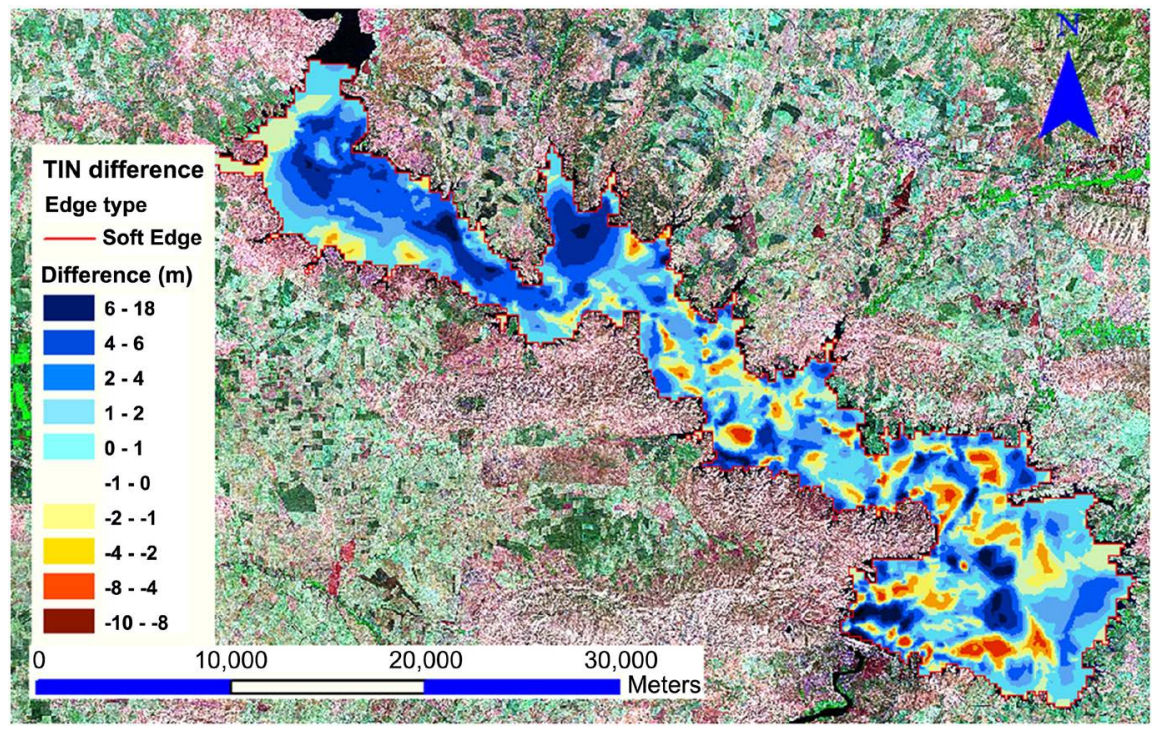

Figure 11. Holes noticed at the bed of Mosul reservoir [73]. 
and jointing. In addition, deep curtain grouting was performed to stop the seepage in the foundations under the dam, also to reduce the permeability of the grouted zone (see Figure 8). Lugeon tests were used to make sure that grouting operations fulfilled the engineering requirements. The aim was to close all the openings within the rocks under the foundation of the dam. Due to the dissolution of gypsum, there were openings created within the deep curtain. To close these openings, massive grouting operations were performed. Despite all the maintenance program, which was carried out seepage of water under the foundation, did not stop and in fact the situation was worsening.

To evaluate the conditions of Mosul Dam, the US Army Corps of Engineers [47] (Kelly et al. 2007) used the rock quality designation (RQD) (Deere and Deere 1989) as an index for the description of rock mass fractured state. This test was performed on samples taken in years of 1989 and 2006. The results showed that the samples were deteriorating where RQD results were $45 \%$ - $65 \%$ for the year 1989 and $0 \%-20 \%$ for the year 2006. It should be mentioned however that these samples were taken within the vicinity of sinkhole SD5 and it does not reflect the real situation of Mosul Dam foundation. In addition, it was noticed that there were places that highly deteriorated within the deep curtain and the dissolution front had progressed $350 \mathrm{~m}$ toward the east i.e. an average of about 17 $\mathrm{m}$ /year. In view of this, the International Board of Experts for Mosul Dam decided to keep the water level within the reservoir at $319 \mathrm{~m}$ a.s.l. [57] [58]. This is to minimize the loses in case of dam failure and it will also decrease the quantity of dissolution of gypsum.

\section{Islamic State of Iraq and Syria (ISIS) Occupation of the Dam Area}

ISIS occupied Mosul Dam area on 8 August 2014 and they were seized back from the hands of ISIS on the 16th of the same month. ISIS destroyed the buildings, equipment, bridges, etc. on the site (Figure 12). As a result, the grouting

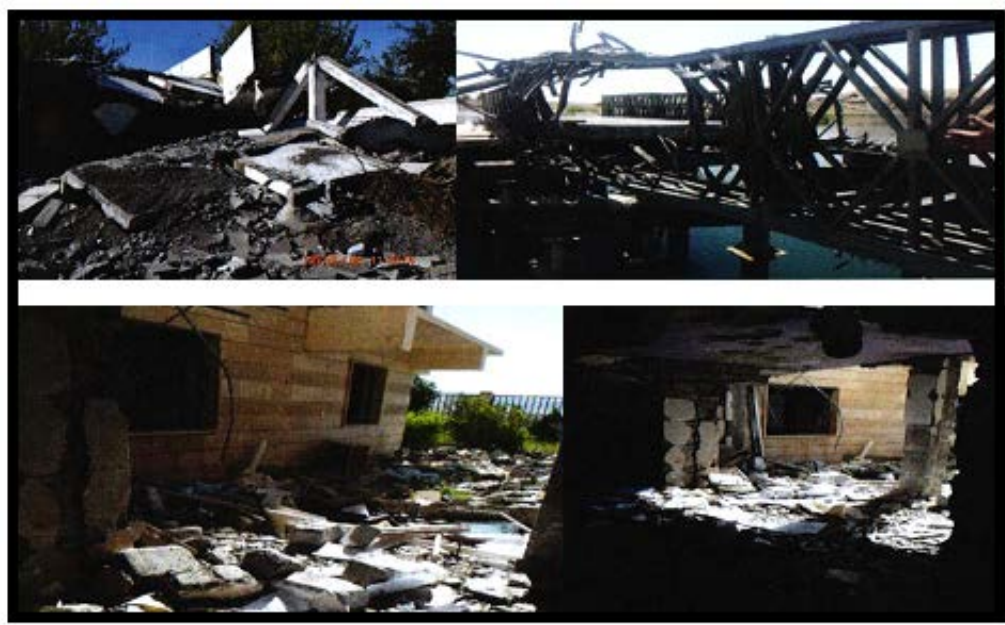

Figure 12. Destructions of buildings and bridge as an example of what ISIS did at Mosul Dam site. 
operations were halted which had been taking place for more than 30 years and had consumed more than 95,000 tons of solid grout materials. In view of this, the number of work was done by the US Army Corps of Engineers in 2015 to carry out measurements, surveys and observations to follow developments that might lead to the dam failure [67]. The results of these investigations estimated that about 10,000 $\mathrm{m}^{3}$ of gypsum were dissolved during the period 2014-2016 due to discontinuation of grouting works which was stopped for few months. All these indications led number of researchers to believe that the am is in very critical conditions [77] [78] [79] [81] [82]. Accordingly number of work was carried out [41] [77] [78] [79] [83] [84] [85] to find out the consequences of dam failure and if the work done by the Swiss Consultants was good enough [86] [87] [88].

\section{Work after ISIS Occupation}

After the defeat of ISIS from Mosul Dam area, the Iraqi Ministry of Water Resources started to rebuild and construct the destroyed parts of the site and started again the maintenance program for the dam (Figure 13). In addition, they signed a contract with an Italian company (Trevi) (contract No. 1002/2016) to do maintenance work at Mosul Dam area. The work mainly included the rehabilitation of one of the bottom outlet gates and grouting.

In addition to the above-mentioned work, the D.G. of Dams did a very good training program with Trevi in maintenance grouting and rehabilitation of bottom outlet for the personnel working (Figure 14) and another course with the US Army Corps of Engineers (Figure 15). After doing these training courses, the

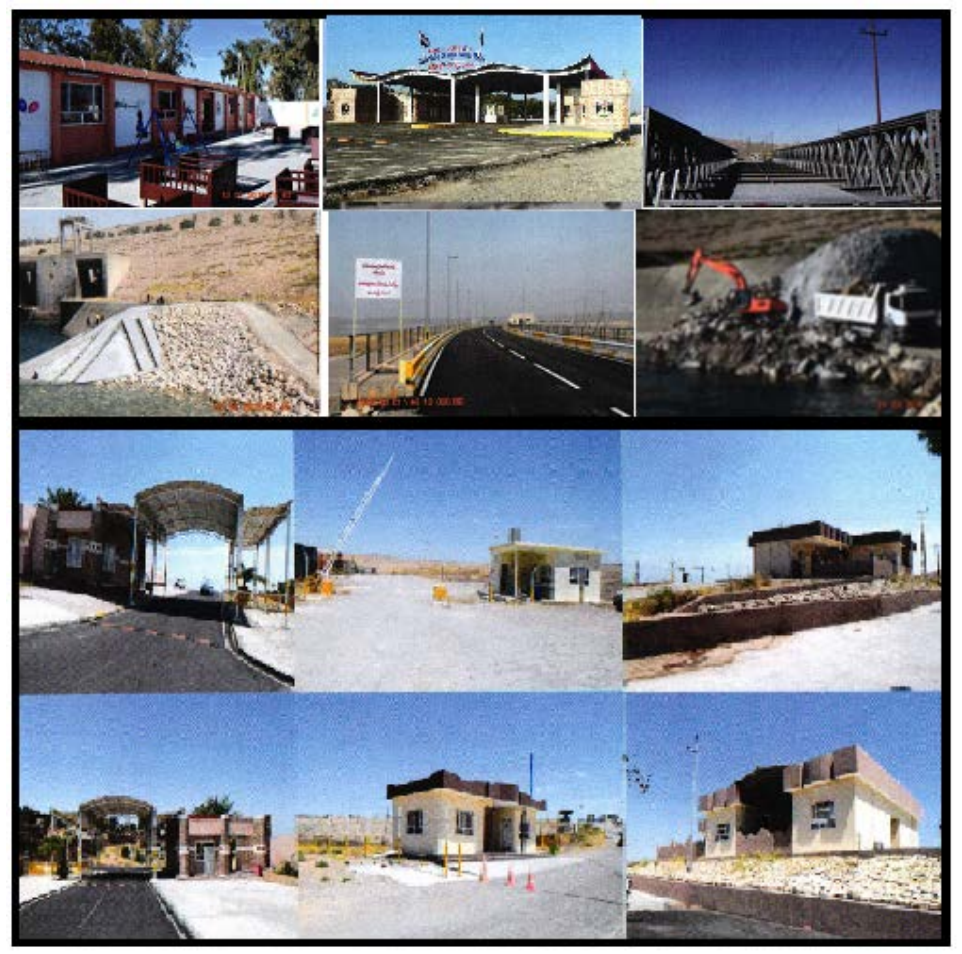

Figure 13. Reconstruction of different sites in Mosul Dam area after ISIS occupation. 


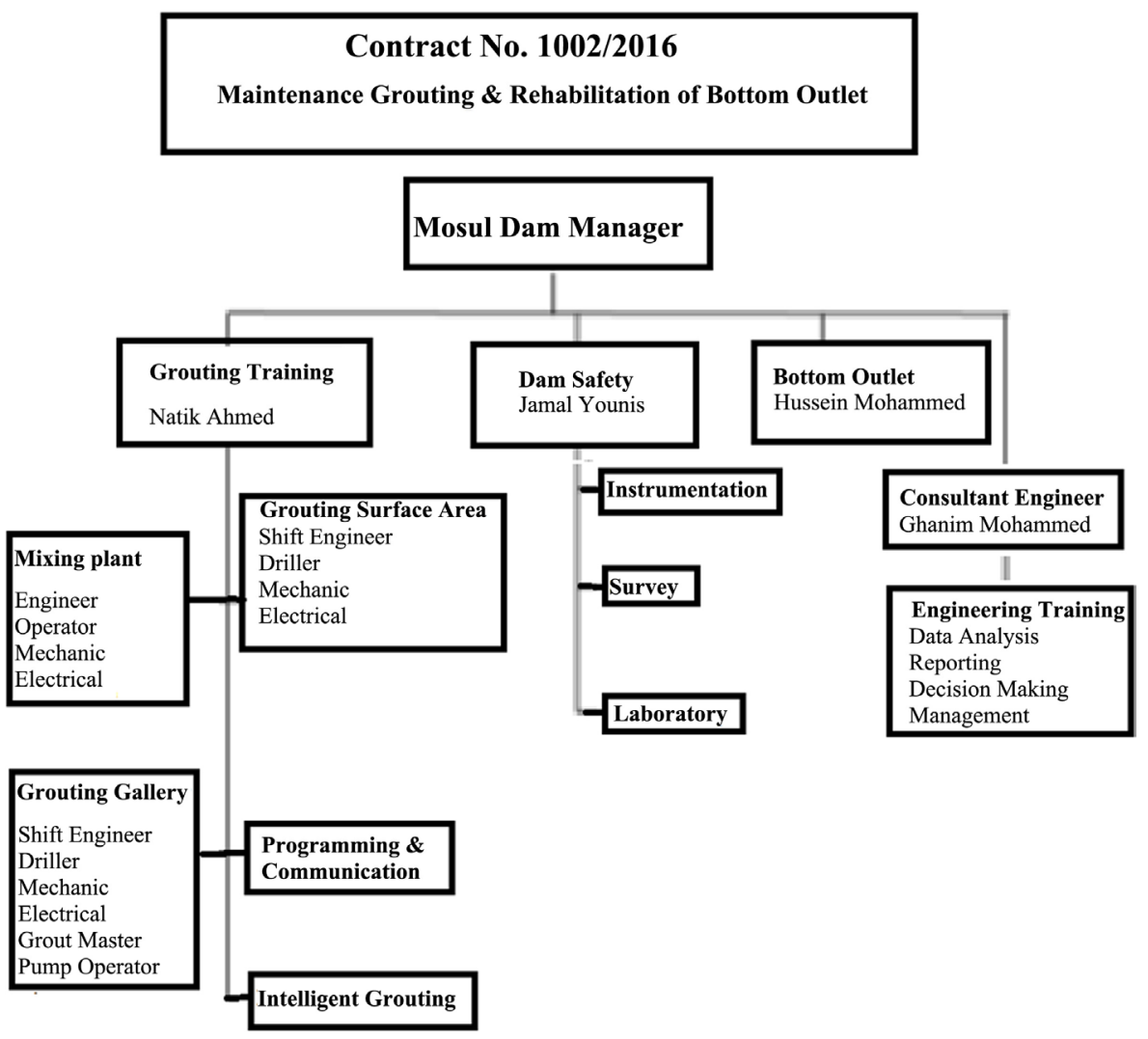

Figure 14. Flow chart of training program for engineers at Mosul Dam with the Italian company "Trevi".

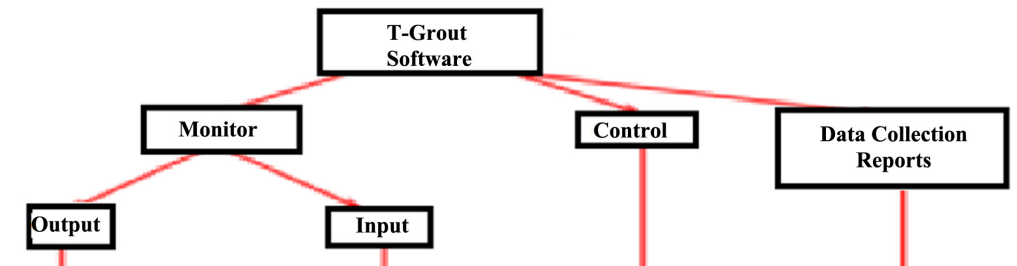

- Data, Start and stop time of Injection

- Gauge effective pressures

- Flow rate of injection

- Lugeon values with grout LUG (instantaneous)

- Grout take (volume) of each grout mix used

- Total Cumulative volume of (all) grouts places

- Volume of mix being Grouted

- Gauge and effective Pressures (instantaneous) Vs time

- Flow rate of injection vs Time

- LUG -Lugeon values with grout

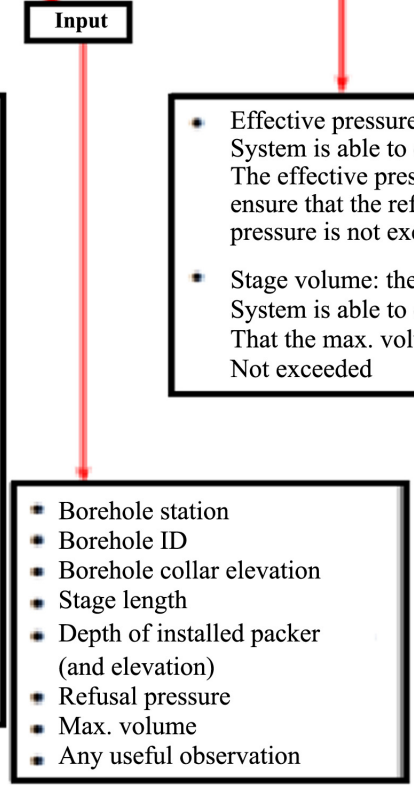

Figure 15. Grouting system used at Mosul Dam site.
Effective pressure: the System is able to control The effective pressure to ensure that the refusal pressure is not exceeded

Stage volume: the System is able to control That the max. volume is Not exceeded

- Stage grouting report

- WPT reports

* Borehole cards

- Daily reports

- AutoCAD profiles

- Others 
staff at Mosul Dam project were qualified to take the responsibilities in maintenance, grouting and operation of the dam.

Grouting operations now follow very highly upgraded system (Figure 15). Furthermore, advanced stations and equipment for preparing and pumping grout mix are used now. All the operation is computerized. All electrical cables (98 km long) were replaced in grouting galleries. Pipes that are used for pumping grout mix (15 km long with 1.5-inch diameter) and water pipes (5.7 km long and 6 inches diameter) were all replaced (Figure 16).

New 18 drilling machine are used now where 11 of them are electric machines and the remainder are diesel-operating machines (Figure 17). All drilling machines are equipped with advanced technologies to register drilling speed, rotations per minute and liquid pressure. This gives accurate information about the beds and all data are displayed on the computer. Three preparation and grout pumping stations were installed that covers all the required areas (Figure 18) and there are 32 secondary grout-pumping stations (Figure 19). It should be mentioned however, that the grout mix is prepared using special computer program to ensure good required specifications (Figure 20). The overall grouting operation is controlled from the control room (Figure 21). From this room all grouting operations are monitored and can be controlled. In addition, all the

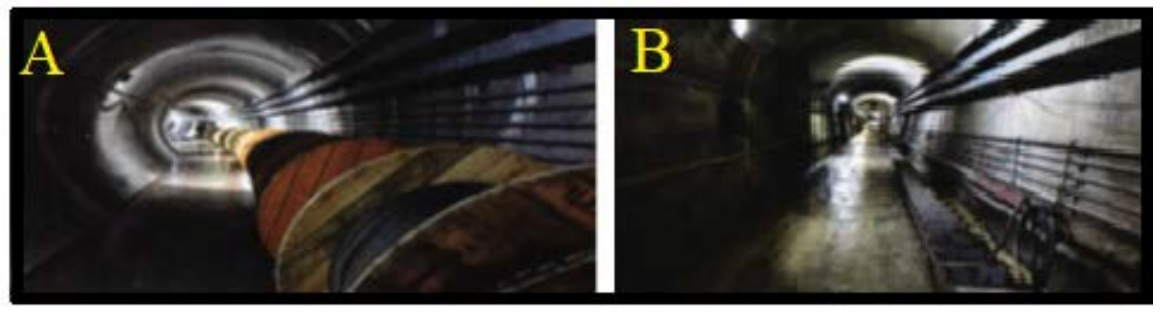

Figure 16. Electrical cables (A) and water pipes (B) were replaced in all galleries at Mosul Dam site.

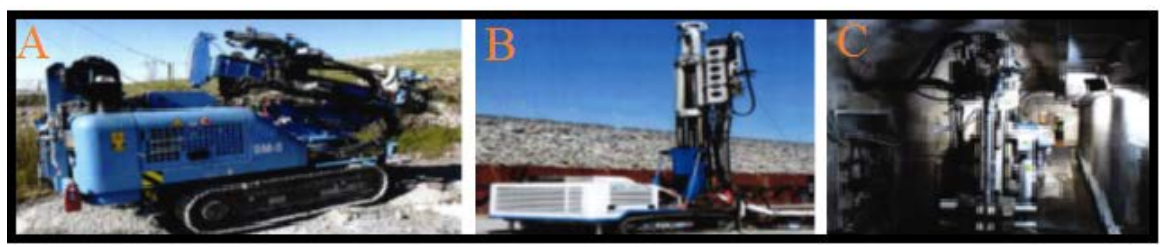

Figure 17. Drilling machines used at Mosul Dam, (A) Small Diesel machine (B) large machine (C) Small machine for tight areas.

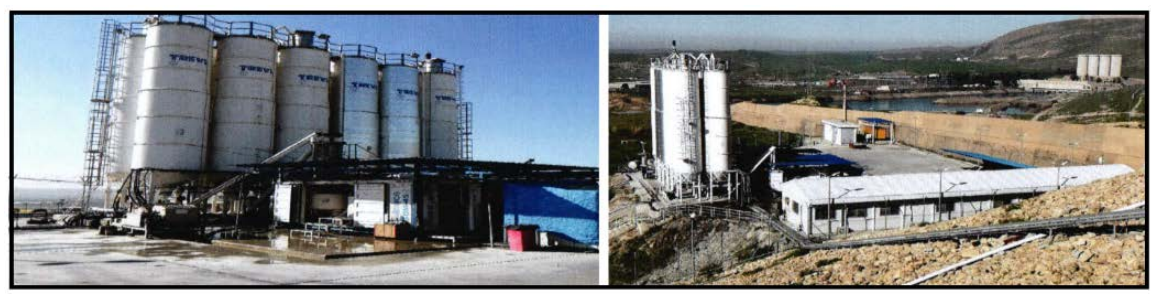

Figure 18. Grout mixing and pumping stations. 


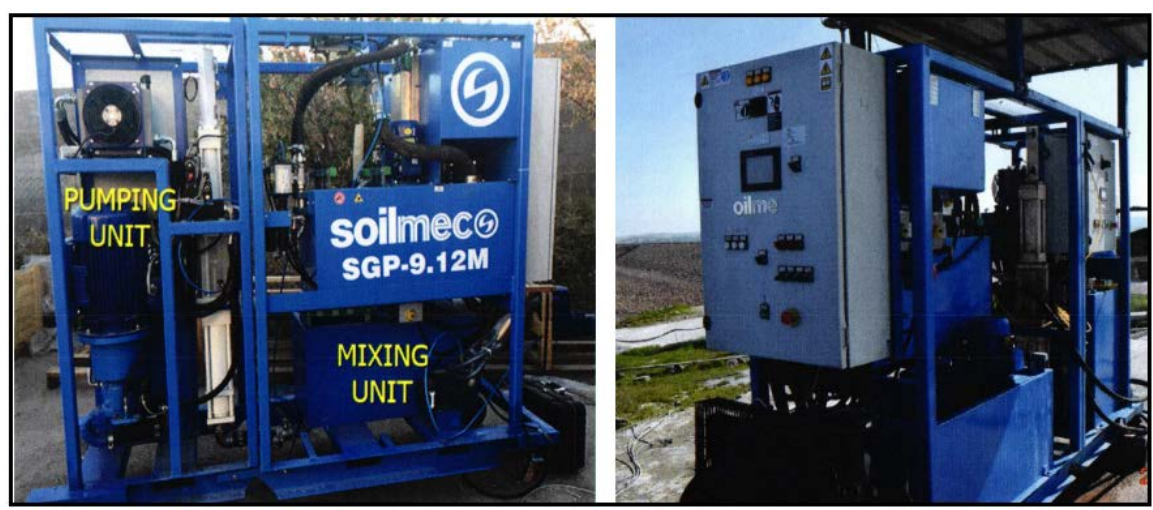

Figure 19. Secondary Grout mixing and pumping stations.

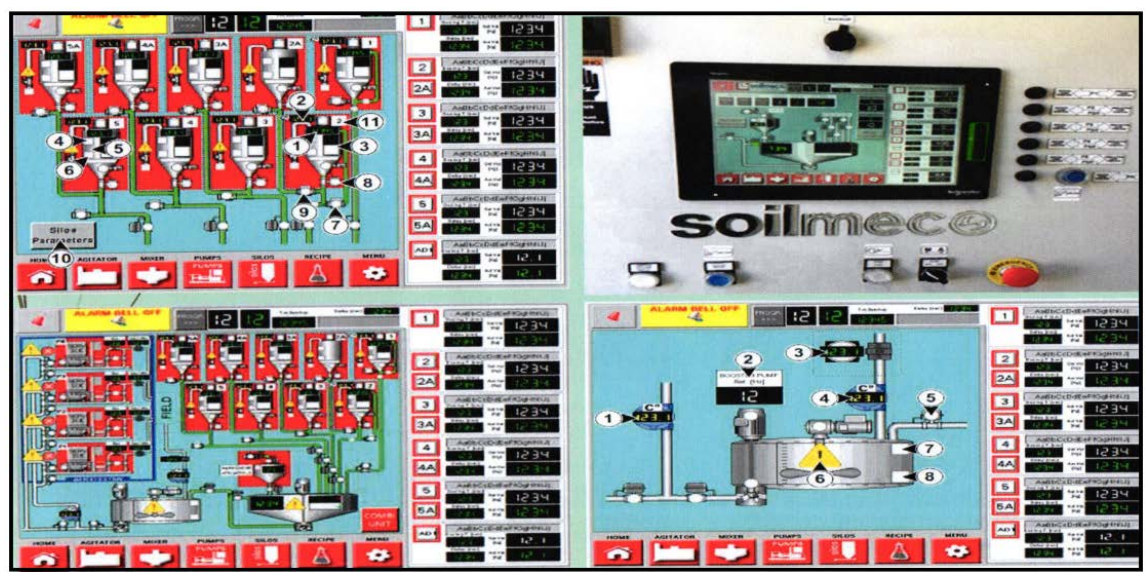

Figure 20. The grout mix is prepared using special computer program to ensure good specifications required.

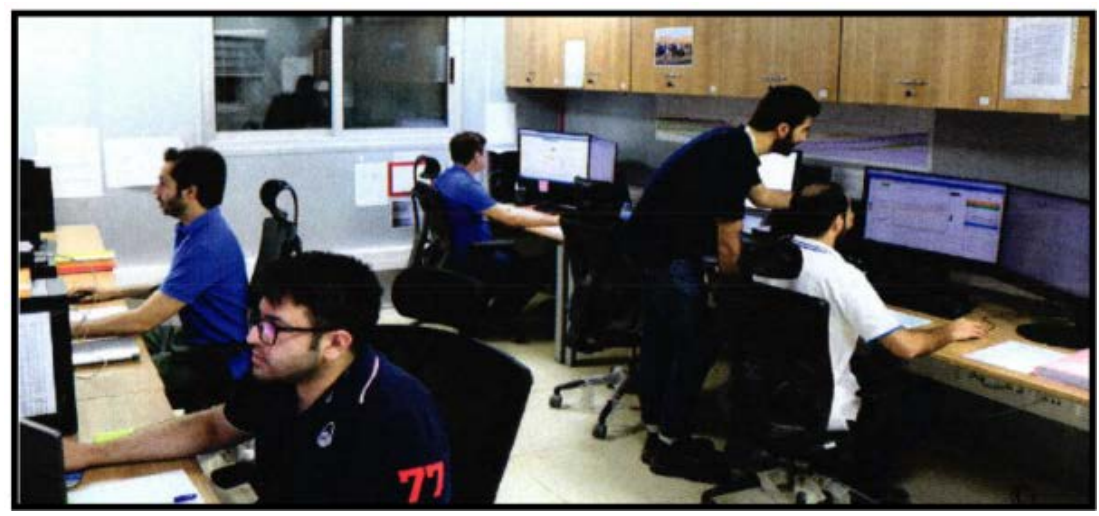

Figure 21. Control room for Grout operations.

data concerning this operation is stored and data base is prepared for all grouting operations.

It is noteworthy to mention that different galleries and tunnels were cleaned and repaired from grout waste mainly Aljazera irrigation tunnel. This tunnel is $450 \mathrm{~m}$ long with $6 \mathrm{~m}$ diameter which is lined by concrete layer $1 \mathrm{~m}$ thick and another iron layer $18 \mathrm{~mm}$ thick (Figure 22). 


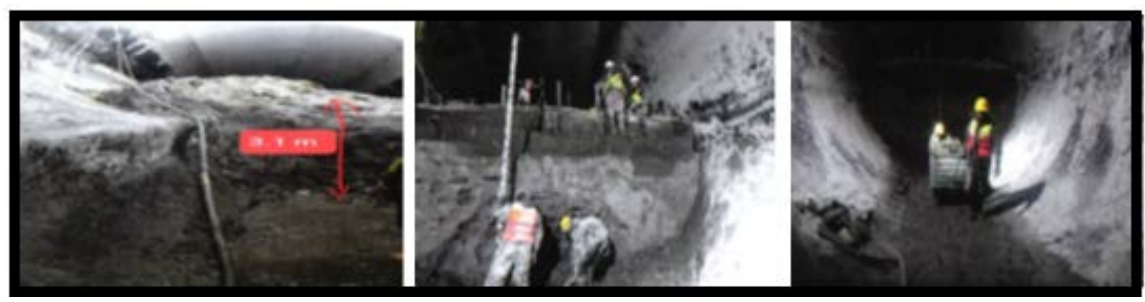

Figure 22. Cleaning operations at Aljazera irrigation tunnel.

\section{Conclusions}

Mosul Dam was built on alternating beds of limestone, gypsum and marls. These rocks were highly karstified and jointed. It seems that there were some geological misinterpretations of the geological conditions of the site. These faulty interpretations can be summarized as follow:

1) The depth drawn by the designers to indicate the depth of grouting to fill all cavities ignored some of the gypsum beds that are present below that depth. It seems that these beds were affected by the water particularly one impounding started. Some of these beds were dissolved and cavities were developed. For this reason, grouting material was going down to these cavities, which are located below the curtain-grouting limit. It should be mentioned however, that if grouting operations for karstified rocks in dam sites are not performed correctly [89], or when performed by using miss interpreted data [42], the results will be negative.

2) Some samples collected from some boreholes were reddish brown clay described as bauxite. Actually, they are Terra Rossa, which is a very good indication for karst [90]. These were not grouted and neglected.

For the above reasons, seepage of water started once the reservoir was impounded. The process of karstification is an ongoing process and expected to continue with the limestone and gypsum beds and for this reason, grouting is to be performed continuously to minimize the seepage. In view of this situation, the International Board of Experts recommended to keep the water level at 219 $\mathrm{m}$ a.s.l. instead of the normal operation level (330 m.a.s.l.). This is to lower the pressure of impounded water on the dam and the rocks on the site to minimize the seepage and the damage will be minimum in case of dam failure.

It is noteworthy to mention that, the present grouting operations and performance of maintenance work by the Iraqi engineers in Mosul Dam site are excellent. This indicates that the dam is safe at its present water level within its reservoir at 319 m.a.s.l. In addition, the impounding was raised 325 m.a.s.l. for few days and nothing abnormal was noticed.

\section{Acknowledgements}

We would like to thank the Iraqi Ministry of Water Resources for providing the data and arranging field trips.

\section{Conflicts of Interest}

The authors declare no conflicts of interest regarding the publication of this paper. 


\section{References}

[1] Al-Ansari, N. (2021) Topography and Climate of Iraq. Journal of Earth Sciences and Geotechnical Engineering, 11, 1-13. https://doi.org/10.47260/jesge/1121

[2] Al-Ansari, N. (2021) Water Resources of Iraq. Journal of Earth Sciences and Geotechnical Engineering, 11, 15-34. https://doi.org/10.47260/jesge/1122

[3] Al-Ansari, N., Adamo, N. and Sissakian, V.K. (2019) Hydrological Characteristics of the Tigris and Euphrates Rivers. Journal of Earth Sciences and Geotechnical Engineering, 9, 1-26.

[4] ESCWA (Economic and Social Commission for Western Asia) (2013) Inventory of Shared Water Resources in Western Asia. Salim Dabbous Printing Co., Beirut, 626 p.

[5] Abdullah, M., Al-Ansari, N. and Laue, J. (2019) Water Resources Projects: Large Storage Dams. Journal of Earth Sciences and Geotechnical Engineering, 9, 109-135.

[6] Abdullah, M., Al-Ansari, N. and Laue, J. (2019) Water Resources Projects in Iraq, Reservoirs in the Natural Depressions. Journal of Earth Sciences and Geotechnical Engineering, 9, 137-152.

[7] Abdullah, M., Al-Ansari, N. and Laue, J. (2019) Water Resources Projects in Iraq: Barrages. Journal of Earth Sciences and Geotechnical Engineering, 9, 153-167.

[8] Abdullah, M., Al-Ansari, N. and Laue, J. (2019) Water Resources Projects in Iraq, Irrigation Projects on Euphrates. Journal of Earth Sciences and Geotechnical Engineering, 9, 169-199.

[9] Abdullah, M., Al-Ansari, N. and Laue, J. (2019) Water Resources Projects in Iraq, Irrigation Projects on Tigris. Journal of Earth Sciences and Geotechnical Engineering, 9, 201-230.

[10] Abdullah, M., Al-Ansari, N. and Laue, J. (2019) Water Resources Projects in Iraq, Irrigation Projects on Tigris River Tributaries. Journal of Earth Sciences and Geotechnical Engineering, 9, 231-247.

[11] Abdullah, M., Al-Ansari, N. and Laue, J. (2019) Water Resources Projects in Iraq, Irrigation. Journal of Earth Sciences and Geotechnical Engineering, V. 9, 4,249-274.

[12] Abdullah, M., Al-Ansari, N. and Laue, J. (2019) Water Resources Projects in Iraq, Main Drains. Journal of Earth Sciences and Geotechnical Engineering, 9, 275-281.

[13] Abdullah, M., Al-Ansari, N. and Laue, J. (2019) Water Resources Projects in Iraq, Medium and Small Storage Dams. Journal of Earth Sciences and Geotechnical Engineering, 9, 283-289.

[14] Abdullah, M., Al-Ansari, N., Adamo, N., Sissakian, V. and Laue, J. (2020) Irrigation Major Systems on Euphrates River within Mesopotamia. Journal of Earth Sciences and Geotechnical Engineering, 10, 199-219.

[15] Abdullah, M. and Al-Ansari, N. (2021) Irrigation Projects in Iraq. Journal of Earth Sciences and Geotechnical Engineering, 11, 35-160.

https://doi.org/10.47260/jesge/1123

[16] Al-Ansari, N.A., Knutsson, S. and Ali, A. (2012) Restoring the Garden of Eden, Iraq. Journal of Earth Sciences and Geotechnical Engineering, 2, 53-88.

[17] Al-Ansari, N. (2019) Agricultural Activities and Hydropolitics of the Tigris and Euphrates Rivers. Conference on the Development of Agricultural Sector in Iraq: problems and Solutions, London, 29 June, 2019.

[18] Al-Ansari, N.A. and Knutsson, S. (2011) Toward Prudent Management of Water Resources in Iraq. Journal of Advanced Science and Engineering Research, 1, 53-67. 
[19] World Bank (2006) Iraq: Country Water Resources, Assistance Strategy: Addressing Major Threats to People's Livelihoods. Report No. 36297-IQ, 97 p.

[20] Al-Ansari, N. (1998) Water Resources in the Arab Countries: Problems and Possible Solutions. UNESCO International Conference on World Water Resources, Paris, 3-6 June 1998, 367-376.

[21] Sadik, A.K. and Barghouti, S. (1995) The Water Problems of the Arab World: Management of Scarce Water Resources. In: Rogers, P. and Lydon, P., Eds., Water in the Arab World, Harvard University Press, Cambridge, 4-37.

[22] IMMPW Iraqi Ministry of Municipalities and Public Work (2011) Water Demand and Supply in Iraq: Vision, Approach and Efforts, GD for Water.

https://www.globalsecurity.org/military/world/iraq/public works.htm

[23] IPCC (2014) "Climate Change 2014 the Physical Science Basis": Contribution of Working Group I to the Fifth Assessment Report of the Intergovernmental Panel on Climate Change. Cambridge University Press, Cambridge.

[24] Adamo, N., Al-Ansari, N., Sissakian, V.K., Knutsson, S. and Laue, J. (2018) Climate Change: Consequences on Iraq's Environment. Journal of Earth Sciences and Geotechnical Engineering, 8, 43-58.

[25] Al-Ansari, N.A., Ali, A.A. and Knutsson, S. (2015) Iraq Water Resources Planning: Perspectives and Prognoses. ICCCE 2015: XIII International Conference on Civil and Construction Engineering, Jeddah, Saudi Arabia, 26-27 January 2015, 2097-2108.

[26] Al-Ansari, N.A. (2016) Hydropolitics of the Tigris and Euphrates Basins. Engineering, 8, 140-172. https://doi.org/10.4236/eng.2016.83015

[27] Al-Ansari, N.A., Abdellatif, M., Ezeelden, M., Ali, S. and Knutsson, S. (2014) Climate Change and Future Long Term Trends of Rainfall at North-East Part of Iraq. Journal of Civil Engineering and Architecture, 8, 790-805. https://doi.org/10.17265/1934-7359/2014.06.014

[28] Al-Ansari, N., Adamo, N., Sissakian, V., Knutsson, S. and Laue, J. (2018) Geopolitics of the Tigris and Euphrates Basins. Journal of Earth Sciences and Geotechnical Engineering, 8, 187-222.

[29] Al-Ansari, N.A. (2013) Management of Water Resources in Iraq: Perspectives and Prognoses. Journal of Engineering, 5, 667-684.

https://doi.org/10.4236/eng.2013.58080

[30] Abbas, N., Wasim, S.A. and Al-Ansari, N.A. (2016) Assessment of Climate Change Impacts on Water Resources of Khabour in Kurdistan, Iraq. J. Environmental Hydrology, 24, 1-21.

[31] Abbas, N., Al-Ansari, N., Wasimi, S. and Al-Rawabdeh, A.M. (2019) Flow Variation of the Major Tributaries of Tigris River Due to Climate Change. Engineering, 11, 437-442. https://doi.org/10.4236/eng.2019.118031

[32] Abbas, N., Wasimi, S.A. and Al-Ansari, N. (2017) Impacts of Climate Change on Water Resources of Greater Zab and Lesser Zab Basins, Iraq, Using Soil and Water Assessment Tool Model. International Journal of Environmental, Chemical, Ecological, Geological and Geophysical Engineering, 11, 823-829. https://doi.org/10.17265/1934-7359/2016.12.009

[33] Abbas, N., Wasimi, S.A. and Al-Ansari, N. (2020) Impacts of Climate Change on Water Resources of Fitzroy River and Tigris River Basins and Identification of Adaptation Measures. PhD Thesis, University of Central Queensland, Rockhampton.

[34] Abbas, N., Wasimi, S.A., Al-Ansari, N. and Nasrin Baby, S. (2018) Recent Trends 
and Long-Range Forecasts of Water Resources of Northeast Iraq and Climate Change Adaptation Measures. Water, 10, 1562. https://doi.org/10.3390/w10111562

[35] IOM (International Orgaization for Migration) (2020) Water Quality and Quantity in Central and South Iraq: A Preliminary Assessment in the Context of Displacement Risk.

https://reliefweb.int/report/iraq/water-quantity-and-water-quality-central-and-sout h-iraq-preliminary-assessment-context

[36] United Nations (UN) (2010) Water Resources Management White Paper. United Nations Assistance Mission for Iraq, United Nations Country Team in Iraq, 20 p. https://www.unwater.org/

[37] Sissakian, S., Adamo, N. and Al-Ansari, N. (2019) The Role of Geological Investigations for Dam Siting: Mosul Dam a Case Study. 1st International Conference on Forecasting Water in the Future of Iraq: Using the Past and Present, Sulaimainyah University, Iraq, 13-15 September.

[38] Iraqi Ministry of Water Resources, Water Resources, Mosul Dam.

[39] Ezz-Aldeen, M., Al-Ansari, N.A. and Knutsson, S. (2012) Sediment Delivery from Right Bank Valleys to Mosul Reservoir, Iraq. Journal of Ecology and Environmental Sciences, 3, 50-53.

[40] Wakeley, L.D., Kelley, J.R., Talbot, C.A., Pearson, M.L. and Broadfoot, S.W. (2007) Geologic Conceptual Model of Mosul Dam. U.S. Army Engineer Research and Development Center, Vicksburg, $61 \mathrm{p}$. https://www.researchgate.net/publication/235070116 Geologic Conceptual Model of Mosul Dam

[41] Washington Group International, Black and Veatch, J.V. (2005) Mosul Dam Study. Final Report, Task Order No. 8, Republic of Iraq Project Contracting Office, Provisional Coalition Authority.

[42] Adamo, N., Al-Ansari, N.A., Sissakian, V., Knutsson, S. and Laue, J. (2018) Mosul Dam: Full Story, Dar Albasghaer Al-Islamiyah, Beruit, 351 p. (In Arabic)

[43] Sissakian, V.K. and Fouad, S.F. (2012) Geological Map of Iraq, Scale 1:1000000. 4th Edition, Iraq Geological Survey Publications, Baghdad. http://www.scirp.org/reference/ReferencesPapers.aspx

[44] Sissakian, V., Al-Ansari, N.A., Issa, I.E., Adamo, N. and Knutsson, S. (2015) Mystery of Mosul Dam the Most Dangerous Dam in the World: General Geology. Journal of Earth Sciences and Geotechnical Engineering, 5, 1-13.

[45] Al-Ansari, N.A., Al-Jabbari, M., Barazachi, A. and Gayarah, A. (1984) Geological, Geophysical and Hydrological Investigation of Mosul Dam Area. Report Submitted to the Iraqi Ministry of Irrigation.

[46] Al-Ansari, N.A., Issa, I.E., Sissakian, V., Adamo, N. and Knutsson, S. (2015) Mystery of Mosul Dam the Most Dangerous Dam in the World: The Project. Journal of Earth Sciences and Geotechnical Engineering, 5, 15-31.

[47] Al-Ansari, N.A., Adamo, N., Issa, I.E., Sissakian, V. and Knutsson, S. (2015) Mystery of Mosul Dam the Most Dangerous Dam in the World: Karstification and Sinkholes. Journal of Earth Sciences and Geotechnical Engineering, 5, 33-45.

[48] IVO, Imatran Voima Osakeyhtio (1969) Consulting Engineers, Finland, Geologic Map of Mosul Dam. Ministry of Agrarian Reform, Baghdad.

[49] Kelly, J., Wakeley, L.D., Broadfoot, S.W., Pearson, M.L., McGill, T.E., Jorgeson, J.D., Talbot, C.A. and McGrath, C.J. (2007) Geologic Setting of Mosul Dam and Its Engineering Implications. Final Report, U.S. Army Engineer District, Gulf Region, 
Baghdad.

[50] Sissakian, V.K. and Al-Mousawi, H.A. (2007) Karstification and Related Problems, Examples from Iraq. Iraqi Bulletin of Geology and Mining, 3, 1-12.

[51] Sissakian, V.K. (1978) Report on the Geological Mapping of Tuz Khurmatu-Kifri-Kalar Area. Iraq Geological Survey Library Report No. 902.

[52] Sissakian, V.K. and Ibrahim, F.A. (2004) Geological Hazards Map of Mosul Quadrangle, Scale 1:250000. Iraq Geological Survey Library Report No. 2860.

[53] Sissakian, V.K., Al-Ansari, N. and Knutson, S. (2014) Karstification Problems in Mosul Dam and Its Assessment, North Iraq. Engineering, 6, 84-92. https://doi.org/10.4236/eng.2014.62012

[54] Swiss Consultants (1979) Mosul Dam Project-Planning Report. State Organization of Dams, Republic of Iraq, Ministry of Irrigation, Vol. 1.

[55] Mark and Wheeler, Mosul Dam Assessment Task Order No. 8. Report on Site Visit, Mosul Dam Library, 3-7 September 2004.

[56] Adamo, N., Al-Ansari, N.A., Laue, J., Knutsson, S. and Sissakian, V. (2017) Risk Management Concepts in Dam Safety Evaluation: Mosul Dam as a Case Study. Journal of Civil Engineering and Architecture, 11, 635-652. https://doi.org/10.17265/1934-7359/2017.07.002

[57] Adamo, N. and Al-Ansari, N.A. (2016) Mosul Dam Full Story: Engineering Problems. Journal of Earth Sciences and Geotechnical Engineering, 6, 213-244.

[58] Adamo, N. and Al-Ansari, N.A. (2016) Mosul Dam Full Story: Safety Evaluation of Mosul Dam. Journal of Earth Sciences and Geotechnical Engineering, 6, 185-212.

[59] Adamo, N., Al-Ansari, N.A., Issa, I.E., Sissakian, V. and Knutsson, S. (2015) Mystery of Mosul Dam the Most Dangerous Dam in the World: Problems Encountered During and after Impounding the Reservoir. Journal of Earth Sciences and Geotechnical Engineering, 5, 47-58.

[60] Adamo, N., Al-Ansari, N., Sissakian, V., Knutsson, S. and Laue, J. (2019) Mosul Dam: Geology and Safety Concerns. Journal of Civil Engineering and Architecture, 13, 151-177. https://doi.org/10.17265/1934-7359/2019.03.001

[61] Adamo, N., Al-Ansari, N.A., Knutsson, S., Laue, J. and Sissakian, S. (2017) Mosul Dam: A Catastrophe Yet to Unfold. Engineering, 9, 263-279. https://doi.org/10.4236/eng.2017.93014

[62] Al-Ansari, N.A., Adamo, N., Sissakian, V., Knutsson, S. and Laue, J. (2017) Is Mosul Dam the Most Dangerous Dam in the World? Review of Previous Work and Possible Solutions. Engineering, 9, 801-823. https://doi.org/10.4236/eng.2017.910048

[63] Sissakian, V., Adamo, N. and Al-Ansari, N. (2020) The Role of Geological Investigations for Dam Siting: Mosul Dam a Case Study. Geotechnical and Geological Engineering, 38, 2085-2096. https://doi.org/10.1007/s10706-019-01150-2

[64] Sissakian, V., Adamao, N., Al-Ansari, N., Knutsson, S. and Laue, J. (2017) Defects in Foundation Design Due to Miss-Interpretation of the Geological Data. A Case Study of Mosul Dam. Scientific Research. Engineering, 9, 683-702.

http://file.scirp.org/Html/5-8102857 78053.htm

https://doi.org/10.4236/eng.2017.97042

[65] Sissakian, V., Al-Ansari, N.A. and Knutsson (2014) Karstification Effect on the Stability of Mosul Dam and Its Assessment, North Iraq. Engineering, 6, 84-92. https://doi.org/10.4236/eng.2014.62012

[66] Sissakian, V., Adamo, N., Al-Ansari, N., Knutsson, S., Laue, J. and Elagely, M. (2018) A Comparative Study of Mosul and Haditha Dams, Iraq: Geological Condi- 
tions. Journal of Earth Sciences and Geotechnical Engineering, 8, 35-52.

[67] Al-Ansari, N., Adamo, N., Knutsson, S., Laue, J. and Sissakian, V. (2020) Mosul Dam: Is It the Most Dangerous Dam in the World? Geotechnical and Geological Engineering Journal, 38, 1-21. https://doi.org/10.1007/s10706-020-01355-w

[68] Al-Ansari, N.A., Issa, E.I. and Knutsson, S. (2013) Nature of the Distributed of the Bed Sediment within Mosul Dam Reservoir, Iraq. Al-Rafidain Engineering Journal, (ARE), 22, 135-141. https://doi.org/10.33899/rengj.2014.87336

[69] Al-Ansari, N.A., Issa, E.I., Sherwani, G. and Knutsson, S. (2013) Sedimentation in the Mosul Reservoir of Northern Iraq. Journal of Environmental Hydrology, 21, Paper 7.

[70] Issa, E.I., Al-Ansari, N.A. and Knutsson, S. (2013) Changes in Bed Morphology of Mosul Dam Reservoir. Journal of Advanced Science and Engineering Research, 3, 86-95.

[71] Issa, E.I., Al-Ansari, N.A. and Knutsson, S. (2013) Sedimentation and New Operational Curves for Mosul Dam, Iraq. Hydrological Sciences Journal, 58, 1-11.

https://doi.org/10.1080/02626667.2013.789138

[72] Issa, E.I., Al-Ansari, N.A. and Knutsson, S. (2013) Assessment of Sedimentation Characteristics and Capacity Curve for Mosul Dam Reservoir, Iraq. 2nd Engineering Scientific Conference, Mosul, 19-20 November 2013, 20 p.

[73] Issa, E.I., Al-Ansari, N.A., Sherwany, G. and Knutsson, S. (2013) Sedimentation Processes and Useful Life of Mosul Dam Reservoir, Iraq. Journal of Engineering, 5, 779-784. https://doi.org/10.4236/eng.2013.510094

[74] Issa, I.E., Al-Ansari, N.A. and Knutsson, S. (2014) Mosul Reservoir Sedimentation Characteristics, Iraq. Journal of Environmental Hydrology, 22, Paper 3.

https://doi.org/10.33899/rengj.2014.87336

[75] Issa, E., Al-Ansari, N.A. and Knutsson, S. (2015) Area-Storage Capacity Curves for Mosul Dam, Iraq Using Empirical and Semi-Empirical Approaches. International Commission on Large Dams "ICOLD" Conference, Hydropower 15, Stavanger, 15-16 June 2015, 22 p.

[76] Al-Abayachi, S. (2016) Report on Mosul Dam, Iraqi House of Representatives. Agriculture, Water, and Marshes Sub-Committee. https://drive.google.com/file/d/0Byn0PFg9wZ5FNHNQUmxLb0JzenM/view

[77] Coffman, R. (2014) Mosul Dam Could Fail If ISIS Doesn't Continue Grouting Operations, Expert Says.

https://www.newswise.com/articles/mosul-dam-could-fail-if-isis-doesn-t-continuegrouting-operations-expert-says-dam-collapse-would-inundate-mosul-and-baghdad

[78] Cetinic, F. (2016) Satellite Based Information to Support Health Analysis of Mosul Dam. International Workshop on Mosul Dam, Stockholm, 24-25 May 2016, 10 p.

[79] Milillo, P., Burgmann, R., Lundgren, P., Salzer, J., Perissin, D., Fielding, E., Biondi, F. and Milillo, G. (2016) Space Geodetic Monitoring of Engineered Structures: The Ongoing Destabilization of the Mosul Dam, Iraq. Scientific Reports, 6, Article No. 37408. http://www.nature.com/articles/srep37408 https://doi.org/10.1038/srep37408

[80] Othman, A.A., Al-Maamar, A.F., Al-Manmi, D.A.M., Liesenberg, V., Hasan, S.E., Al-Saady, Y.I., Shihab, A.T. and Khwedim, K. (2019) Application of DInSAR-PSI Technology for Deformation Monitoring of the Mosul Dam, Iraq. Remote Sensing, 11, 2632. http://www.mdpi.com/journal/remotesensing https://doi.org/10.3390/rs11222632 
[81] MaCleanathan, J.T. (2009) Update for Screening Portfolio Risk Analysis for U.S. Army Corps of Engineers Dams. Risks and Reliability Directorate, USACE.

[82] U.S. Department of the Interior Bureau of Reclamation (2014) Interim RCEM: Reclamation Consequence Estimating Methodology. Guidelines for Estimating Life Loss for Dam Safety Risk Analysis, February.

[83] L-Taiee, T.M. and Rasheed, M.M. (2009) Simulation Tigris River Flood Wave in Mosul City Due to Hypothetical Mosul Dam. Thirteenth International Water Technology Conference, IWTC 13 2009, Hurghada, 12-15 March, 2009.

[84] Mahmud, M.I., Al Azawi, A.O., Abdul Majeed, A.T. and Khalil, T.W. (2015) Mosul Dam Break Scenario and Its Effects on the Areas along the River Down to Baghdad. Ministry of Higher Education and Scientific Research, Center for Catastrophes Data Management and Space Archives, Baghdad. (In Arabic)

[85] Annunziato, A., Andredakis, I. and Probst, P. (2016) Impact of Flood by a Possible Failure of the Mosul Dam, Version 2. Joint Research Centre (JRC) Technical Reports, EU Commission, April 2016. https://publications.jrc.ec.europa.eu

[86] Swiss Consultants Consortum (1984) Mosul Dam Flood Wave, Summary, Vol. I, Feb. 1984.

[87] Swiss Consultants Consortum (1984) Mosul Dam Flood Wave, Model Calibration, Vol. II, Feb. 1984.

[88] Swiss Consultants Consortum (1984) Mosul Dam Flood Wave, Calculation, Vol. III, Feb. 1984

[89] Bonacci, O., Gottstein, S. and Roja-Bonacci, T. (2009) Negative Impacts of Grouting on the Underground Karst Environment. Echohydrology, 2, 492-502. http://www.nat-hazards-earth-syst-sci.net/13/2041/2013/nhess-13-2041-2013.pdf https://doi.org/10.1002/eco.90

[90] Merino, E., Banerjee, A. and Dworkin, S. (2006) Dust, Terra Rossa, Replacement, and Karst: Serendipitous Geodynamics in the Critical Zone. Geochimica et Cosmochimica Acta, 70, A416. http://www.deepdyve.com/lp/elsevier/dust-terra-rossa https://doi.org/10.1016/j.gca.2006.06.837 